\title{
Electrostatic interplay: The interaction triangle of polyamines, silicic acid, and phosphate studied through turbidity measurements, silicomolybdic acid test, and ${ }^{29}$ Si NMR spectroscopy
}

\author{
Anne Jantschke, Katrin Spinde and Eike Brunner
}

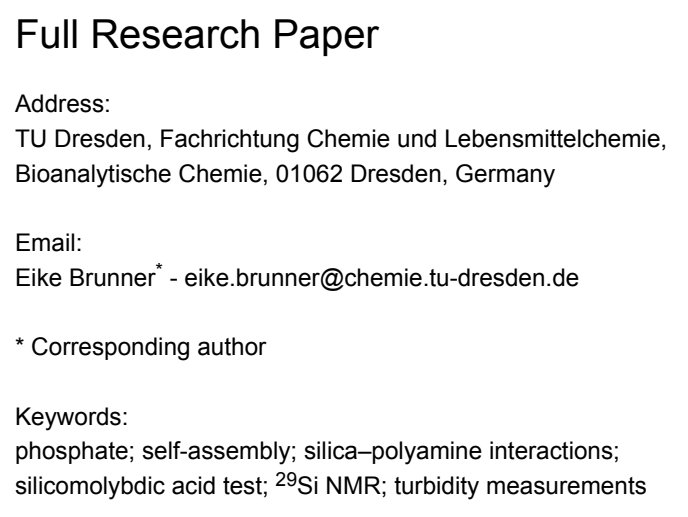

Beilstein J. Nanotechnol. 2014, 5, 2026-2035.

doi:10.3762/bjnano.5.211

Received: 10 June 2014

Accepted: 14 October 2014

Published: 06 November 2014

This article is part of the Thematic Series "Towards multifunctional inorganic materials: biopolymeric templates".

Guest Editors: C. Steinem and J. Bill

(C) 2014 Jantschke et al; licensee Beilstein-Institut.

License and terms: see end of document.

\begin{abstract}
The discovery of long-chain polyamines as biomolecules that are tightly associated to biosilica in diatom cell walls has inspired numerous in vitro studies aiming to characterize polyamine-silica interactions. The determination of these interactions at the molecular level is of fundamental interest on one hand for the understanding of cell wall biogenesis in diatoms and on the other hand for designing bioinspired materials synthesis approaches. The present contribution deals with the influence of amines and polyamines upon the initial self-assembly processes taking place during polyamine-mediated silica formation in solution. The influence of phosphate upon these processes is studied. For this purpose, sodium metasilicate solutions containing additives such as polyallylamine, allylamine and others in the presence/absence of phosphate were investigated. The analyses are based mainly on turbidity measurements yielding information about the early aggregation steps which finally give rise to the formation and precipitation of silica.
\end{abstract}

\section{Introduction}

Long-chain polyamines (LCPAs) were previously found biomolecules that are tightly associated to the biosilica of various diatom species [1-5]. They consist of linear oligopropyleneimine chains attached to putrescine or spermine $[5,6]$.
Biosilica-associated LCPAs occur either as free molecules $[1,4]$ or covalently attached to the $\varepsilon$-amino groups of certain lysineresidues $[7,8]$ in highly post-translationally modified peptides, so-called silaffins [7-10]. It is, furthermore, remarkable that the 
amine moieties in LCPAs from diatoms are partially methylated. The degree of methylation depends on the diatom species. LCPAs have also been identified in the silica spicules of sponges [11] and thus appear to be a general component for biological silica formation. In vitro experiments with LCPAs extracted from diatom biosilica revealed that these molecules are capable of enhancing the silica precipitation from silicic acid solutions [2,5]. It is very remarkable that the silica precipitation process is extremely rapid if the solutions contain phosphate or other suitable counterions in addition to LCPAs and silicic acid $[2,3,12]$. These observations have inspired numerous in vitro investigations to understand the underlying selfassembly processes and interactions [13-30]. Corresponding in vitro investigations using polyallylamine (in form of polyallylamine hydrochloride, PAH) as a synthetic analogue [15] for native LCPAs revealed that phosphate is capable of inducing the self-assembly of PAH into large aggregates that could be detected by dynamic light scattering (DLS) experiments $[16,17]$. Self-assembled PAH aggregates were shown to strongly enhance the speed of silica precipitation, which takes place at a time scale of seconds or minutes. In the absence of phosphate, solutions containing polyallylamine and silicic acid are capable of forming so-called polyamine-stabilized silica sols [18]. These stabilized sols exhibit particles of 30-50 nm diameter, which remain stable up to $24 \mathrm{~h}$. In the relevant $\mathrm{pH}$ range of 5-7, monosilicic acid is an uncharged molecule, $\mathrm{Si}(\mathrm{OH})_{4}$ [31]. However, monosilicic acid ( $\mathrm{p} K_{\mathrm{a}} \approx 9.8$ ) spontaneously transforms into higher oligomers and silica particles $\left(\mathrm{p} K_{\mathrm{a}} \approx 6-7\right)$ [19] which exhibit a negative surface charge in solution. It was, therefore, suggested that the stabilized sol consists of polyamine-silica nanoparticle superstructures resulting from a self-assembly process driven by attractive interactions between positively charged polyamines and negatively charged silica particles $[18,20]$. Subsequent in vitro studies support the idea of polyamine-stabilized sols $[21,22]$. In contrast to the charged $\mathrm{PAH}$, uncharged polymers such as polyvinylpyrrolidone or polyethylene glycol cannot undergo such a self-assembly process driven by electrostatic interactions $[23,24]$. However, they interact with the silicic acid/silica species via hydrogen bonding and possibly hydrophobic interactions. These interactions even result in the stabilization of mono- and disilicic acid species $[22,23]$. The described observations have meanwhile lead to numerous biomimetic or bioinspired silica synthesis approaches [21,25-32].

The addition of negatively charged phosphate ions (see above) to pure LCPA solutions has already been studied in detail. Phosphate results in a cross-linking of the positively charged LCPAs. The resulting self-assembly processes give rise to the formation of a microemulsion finally leading to macroscopic phase separation. It was concluded that the phosphate-driven self-assembly processes are accelerating the silica-precipitation processes. However, the self-assembly processes going on in LCPA/silicic acid/phosphate solutions have not yet been studied in detail — in contrast to the pure LCPA/phosphate system $[12,16,17]$. Further understanding of the molecular interactions between polyamines, silicic acid/silica species and phosphate is, therefore, a rewarding research topic. The aim of the present study is the analysis of the influence of the polyamine structure and charge upon the polycondensation of silicic acid in the absence and presence of phosphate. The kinetics of the aggregation and silica polycondensation processes were studied by a combination of turbidity measurements and silicomolybdic acid test $[31,33,34]$. The study includes the monomeric allylamine, its fully methylated analogue allyltrimethylammonium bromide (allylamineQ) and the widely used long-chain model polyamine poly(allylamine) hydrochloride (PAH). Moreover, a homologous series of diamines with different degree of methylation was studied in order to visualize the possible influence of hydrophobic interactions. For ${ }^{29} \mathrm{Si}$ NMR spectroscopy aqueous solutions of isotope-labelled sodium $\left[{ }^{29} \mathrm{Si}\right]$ metasilicate as precursor compound were used. Different silica precursors, such as toxic TMOS (tetramethyl orthosilicate) or TEOS (tetraethyl orthosilicate), have been used for previous in vitro experiments. Here we used the biorelevant sodium metasilicate as silicic acid precursor. Sodium metasilicate dissolves in water to silicic acid $\left(\mathrm{Na}_{2} \mathrm{SiO}_{3}+3 \mathrm{H}_{2} \mathrm{O} \rightarrow \mathrm{Si}(\mathrm{OH})_{4}+\mathrm{NaOH}\right)$ at a $\mathrm{pH}$ value of $11.5-12.5$ and can subsequently be acidified. Another benefit of using sodium metasilicate is the relatively high sodium concentration since it is known that silicon uptake and transport are connected with the sodium metabolism of diatoms $[35,36]$.

\section{Results and Discussion}

Two of the most important parameters influencing the polycondensation reaction of silicic acid [31] are concentration [37] and $\mathrm{pH}$ value [38]. The maximum polycondensation rates occur around $\mathrm{pH} 7$ [31,38]. It should be noted that the formation of diatom cell walls takes place in the so-called silica deposition vesicle (SDV) with an internal pH of 5-6 [39-42]. Previous in vitro experiments were carried out by Sumper et al. at $\mathrm{pH} 6.8$ $[3,27]$. Other experimentalists have chosen $\mathrm{pH} 5.5$ [2,23,24]. We have therefore carried out experiments at both $\mathrm{pH}$ values, ca. 7 and 5.5.

At $\mathrm{pH}>12$, the silicic acid solutions (in the form of silicate) remain stable even at high concentrations [23,31]. The same is true under very acidic conditions. However, ${ }^{29} \mathrm{Si}$ HR NMR measurements (Figure 1) of sodium metasilicate solutions without any additive reveal that the state of the silicic acid is different for the basic ( $\mathrm{pH}$ 12.5) and the acidic environment ( $\mathrm{pH}$ 1.95). In the basic environment, the signals of $\mathrm{Q}_{0}$ and $\mathrm{Q}_{1}$ 
are dominating the spectrum $\left(\mathrm{Q}_{n}=\mathrm{Si}(\mathrm{OSi})_{n}(\mathrm{OH})_{4-n}, n=0-4\right)$ [43]. Note that highly mobile species exhibit narrow signals as observed in basic solution. In contrast, the spectrum of the acidic solution already exhibits the $\mathrm{Q}_{2}, \mathrm{Q}_{3}$, and $\mathrm{Q}_{4}$ signals characteristic for higher oligomers which are broadened due to an increasing degree of immobilization. That means the condensation reaction is more advanced in the acidic solution whereas the basic solution mainly consists of $\mathrm{Q}_{0}$ and $\mathrm{Q}_{1}$ species. It should be noted that these two species are rapidly interconverting. The sum of $\mathrm{Q}_{0}$ and $\mathrm{Q}_{1}$ represents the so-called "soluble silica" and can be detected by the silicomolybdic acid test reaction $[31,33,34]$. In the basic solution, practically all silica is soluble, i.e., molybdate-reactive. For this reason, our experiments were carried out starting from a basic sodium metasilicate solution.

Figure 2 shows the concentration of soluble silica as a function of $\mathrm{pH}$ determined by the silicomolybdic acid test. A pure sodium metasilicate solution and a solution containing sodium metasilicate and PAH are compared. The interaction between silicic acid/silica species and PAH is assumed to be mediated by the $\mathrm{NH}_{2}$ groups. Therefore, the $\mathrm{PAH}$ concentration was chosen to obtain a $\mathrm{Si} / \mathrm{N}$ ratio of $1: 1$. In the pure sodium metasilicate solution, all silica is detected by the silicomolybdic acid test reaction at $\mathrm{pH}$ 11.5. However, the amount of soluble silica steadily decreases with decreasing $\mathrm{pH}$. In the $\mathrm{pH}$ range of 5-7, more than $95 \%$ of the initial silicic acid are present in the form of insoluble silica. This is the result of the silica polycondensation reaction, which transforms soluble silica species into insoluble silica species, i.e., higher oligomers or silica nanoparticles.

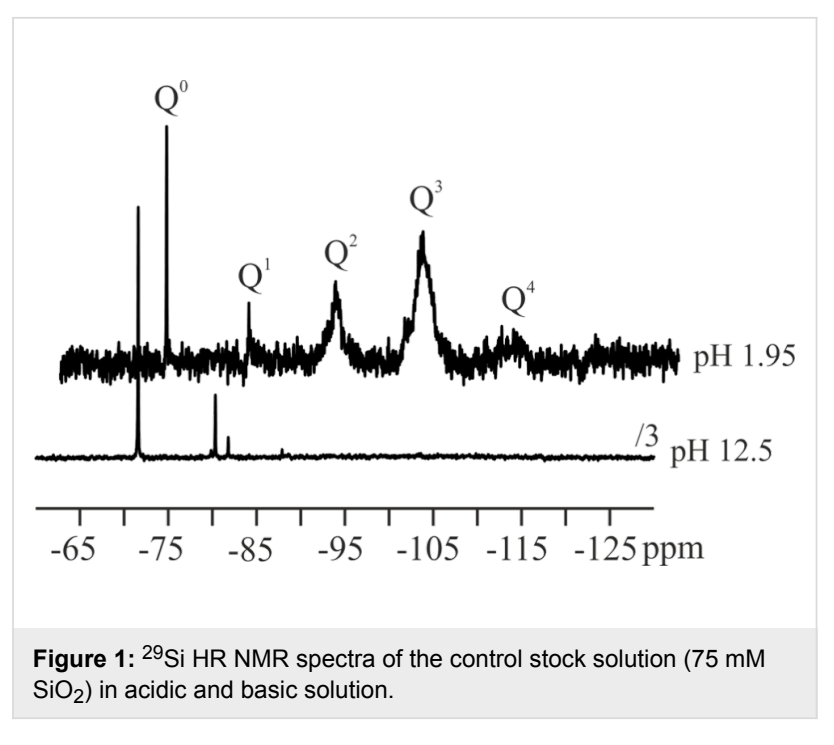

Such insoluble silica species are not detected by the silicomolybdic acid test. It is remarkable that the presence of PAH strongly influences the amount of soluble silica, i.e., the silica polycondensation reaction. The concentration of soluble silica in the PAH-containing sample is always lower than in the PAHfree control. The most pronounced difference between the pure and the PAH-containing sodium metasilicate solution occurs in the $\mathrm{pH}$ range between 11.5 and 8.5 . The $\mathrm{p} K_{\mathrm{a}}$ of $\mathrm{PAH}$ amounts to ca. $9.7[44,45]$ and the $\mathrm{p} K_{\mathrm{a}}$ of $\mathrm{Si}(\mathrm{OH})_{4}$ to circa 9.8. That means PAH is positively charged for $\mathrm{pH}<9.7$ and $\mathrm{Si}(\mathrm{OH})_{4}$ is negatively charged for $\mathrm{pH}>9.8$. Hence, purely electrostatic interactions between the polyamine and monosilicic acid cannot be expected.

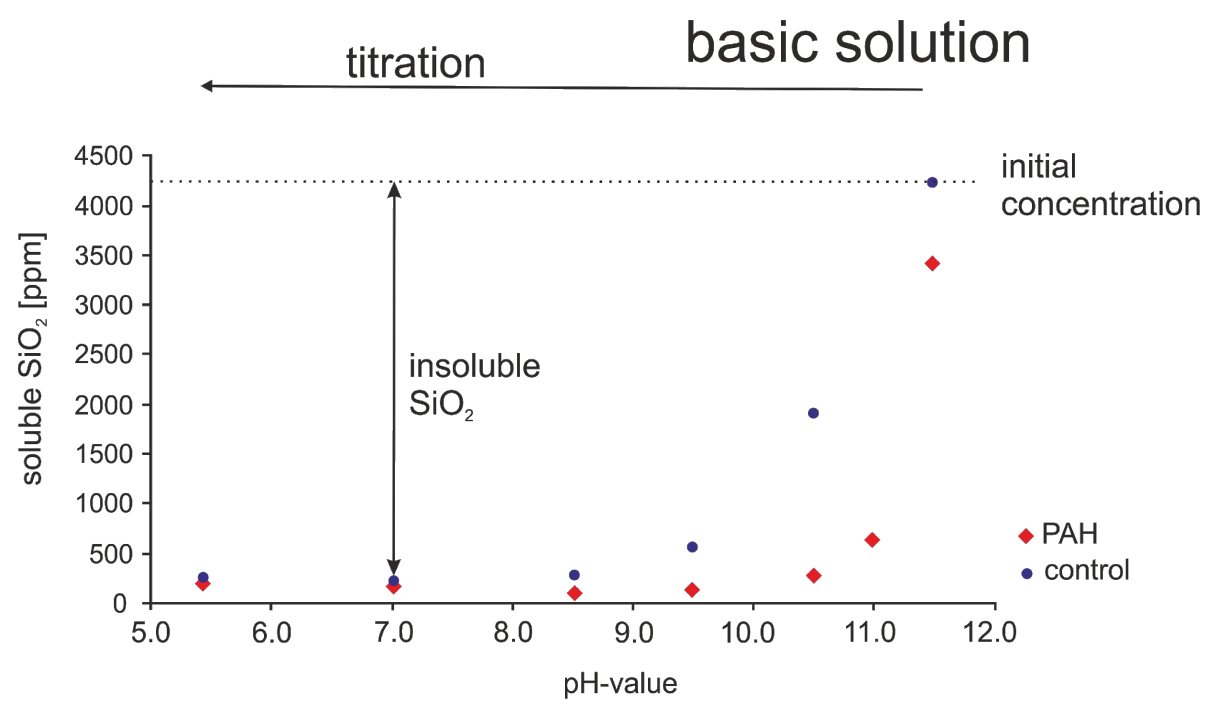

Figure 2: Soluble silicic acid concentration at different $\mathrm{pH}$ values in the presence (red rhombuses) and absence (control, blue circles) of $\mathrm{PAH}$. SiO 2 concentration $70 \mathrm{mM}(4200 \mathrm{ppm})$; PAH concencation $0.45 \mathrm{mM}$. The silicomolybdic acid test reaction was performed 30 min after sample preparation/ $\mathrm{pH}$ titration. 
In contrast to monosilicic acid, higher silicic acid oligomers/ silica nanoparticles exhibit lower $\mathrm{p} K_{\mathrm{a}}$ values. For fumed silica, two different types of silanol groups are reported with $\mathrm{p} K_{\mathrm{a}}$ values of ca. 8 and $4.5[46,47]$. It can therefore be assumed that, in the relevant $\mathrm{pH}$ range of 5-7, the silica nanoparticles exhibit a negative surface charge. Electrostatic interactions will, therefore, occur between the positively charged polyamine and negatively charged higher silicic acid oligomers/silica nanoparticles below the $\mathrm{p} K_{\mathrm{a}}$ of $\mathrm{PAH}$. The resulting immobilization of higher silicic acid oligomers could indeed be observed by ${ }^{29} \mathrm{Si}$ NMR spectroscopy previously [23]. The soluble silica (mono- and disilicic acid) is almost completely polycondensed into insoluble species (higher silica oligomers/nanoparticles) below pH 9 after $30 \mathrm{~min}$ in pure sodium metasilicate as well as the $\mathrm{PAH}$ containing sample (see Figure 2). The PAH-containing sample exhibits a white precipitate whereas the pure sodium metasilicate solution has formed a gel.

\section{Turbidity measurements}

Turbidity measurements provide a simple possibility for the time-resolved study of self-assembly processes in solutions containing organic molecules and silicic acid as has been demonstrated by Robinson et al. [48]. The process of selfassembly and silica polycondensation reaction increases the turbidity of the solution, which causes an increasing absorption. This property can easily be determined with a spectrophotometer and provides a measure for the speed of the ongoing aggregation processes $[48,49]$. Moreover, the turbidity, i.e., the absorbance is influenced by the size and number of aggregates formed in solution. We chose $90 \mathrm{mM}$ silicic acid concentration for measurements at a reasonable timescale (up to $800 \mathrm{~min}$ ) following Robinson et al. [48]. The silica polycondensation is very fast at the $\mathrm{PAH}$ concentrations applied in the experiments as shown in Figure $2(0.45 \mathrm{mM})$ in the relevant $\mathrm{pH}$ range between 5 and 7. Hence, we have decreased the PAH concentration down to $31.25 \mu \mathrm{M}$ in order to prevent rapid silica precipitation at the timescale of the turbidity measurements. The results are shown in Figure 3.

Figure 3 displays the absorbance of a solution with pure sodium metasilicate solution ( $90 \mathrm{mM}$ silicic acid) and a solution with $90 \mathrm{mM}$ silicic acid plus $31.25 \mu \mathrm{M}$ PAH at $\mathrm{pH}$ values of 5.5 and 6.8. The absorbance of the pure sodium metasilicate solution increases much faster at $\mathrm{pH} 6.8$ than at $\mathrm{pH}$ 5.5. This is obviously due to the fact that the maximum speed of silica polycondensation is expected around $\mathrm{pH}$ 7. The addition of $\mathrm{PAH}$ to the sodium metasilicate solutions strongly enhances the absorbance at $\mathrm{pH}$ 6.8. That means the polyamine additive pronouncedly accelerates the aggregation process, which can be explained by the electrostatic interactions between the positively charged PAH and negative surface charges of higher silica oligomers/ silica nanoparticles rapidly forming at $\mathrm{pH} 6.8$. At $\mathrm{pH} 5.5$, the absorbance for both samples slowly increases after an induction period of ca. $100 \mathrm{~min}$. In contrast to the behavior found at $\mathrm{pH} 6.8$, the addition of PAH has almost no effect at $\mathrm{pH} 5.5$, the absorption of the PAH-containing sample is even slightly smaller than in the control solution. It is remarkable that this rather small change of $\mathrm{pH}$ by 1.3 units gives rise to such a pronounced change in the aggregation behavior. The two samples exhibit an identical overall composition except for the $\mathrm{pH}$ and amount of chloride resulting from the titration with $\mathrm{HCl}$. With respect to the charges of the aggregating molecules, the change in $\mathrm{pH}$ will result in the following: The total charge of PAH may become slightly more positive. For monomeric allylamine, the $\mathrm{p} K_{\mathrm{a}}$ value is known to be 9.49 . That means allylamine would be positively charged at both $\mathrm{pH}$ values, 5.5 . and 6.8. However, the $\mathrm{p} K_{\mathrm{a}}$ values of polyallylamine, i.e., of allylamine in its polymeric form, are likely to be different from the
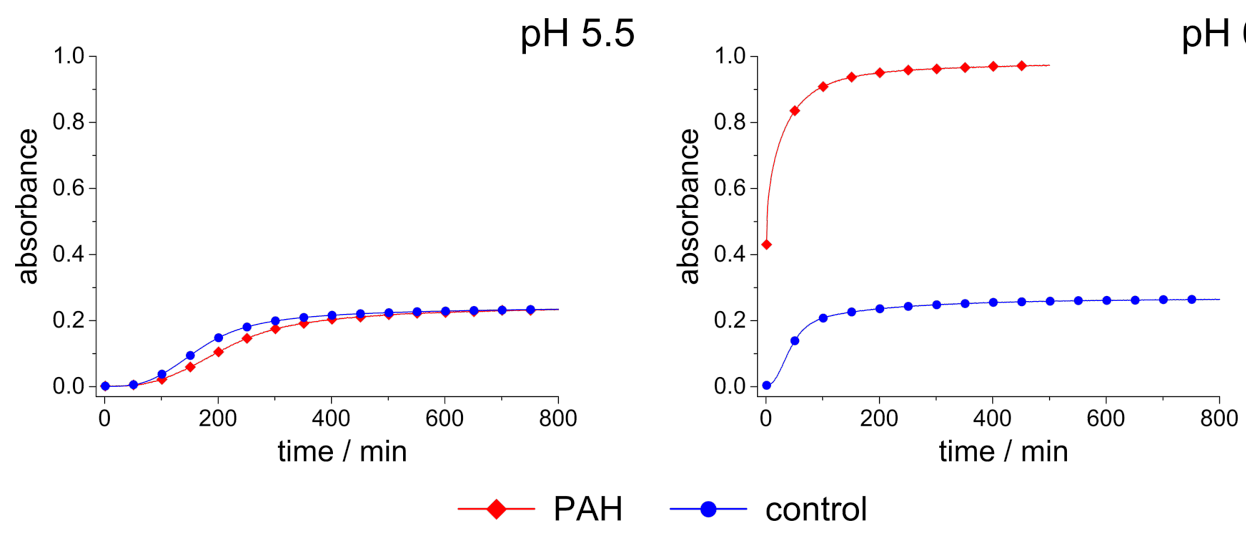

Figure 3: Absorbance of a $90 \mathrm{mM}$ sodium metasilicate solution with $31.25 \mu \mathrm{M} \mathrm{PAH}$ (red rhombuses) and of a pure sodium metasilicate solution (control, blue circles) measured as a function of time up to $800 \mathrm{~min}$. 
monomer. Kobayashi et al. and Rao et. al. estimated a $\mathrm{p} K_{\mathrm{a}}$ value of 9.7 for polyallylamine $[44,45]$. The real charge state of PAH is yet hardly predictable, but it should be supposed that a decreasing $\mathrm{pH}$ results in an increasingly positive charge. Moreover, the silica oligomers/nanoparticles in solution are supposed to exhibit a decreasingly negative surface charge at decreasing $\mathrm{pH}$. If so, the repulsion among the increasingly positive $\mathrm{PAH}$ molecules would not be compensated by attractive forces with the negatively charged silica oligomers/nanoparticles. Consequently, the aggregation process would be suppressed below a certain $\mathrm{pH}$, as is indeed observed for $\mathrm{pH}$ 5.5. If the lack of negative charges is indeed the problem, the capability of the system to self-aggregate should be restored by the introduction of negatively charged ions that themselves do not destructively interfere with the PAH/silica system. This should be the case for phosphate, which is already known to enhance silica precipitation from polyamine/silicic acid solutions. The influence of phosphate upon the sample at $\mathrm{pH} 5.5$ is demonstrated in Figure 4. As predicted, the phosphate-containing solution exhibits a rapidly increasing, strong absorbance which indicates aggregate formation. In the case of the PAH-free control sample, the negatively charged phosphate has the opposite effect: The aggregation becomes even slower than in the phosphate-free sodium metasilicate solution (cf. Figure 3). This can be explained by the fact that the repulsion among the silica oligomers/nanoparticles with their negative surface charge and the phosphate ions further retards the aggregation processes. It can, therefore, be concluded that charge balance is one major parameter determining the speed of aggregation in the polyamine-silica system. Perturbed charge balance can be restored at decreasing $\mathrm{pH}$ by introducing phosphate or other appropriate anions into the solutions.

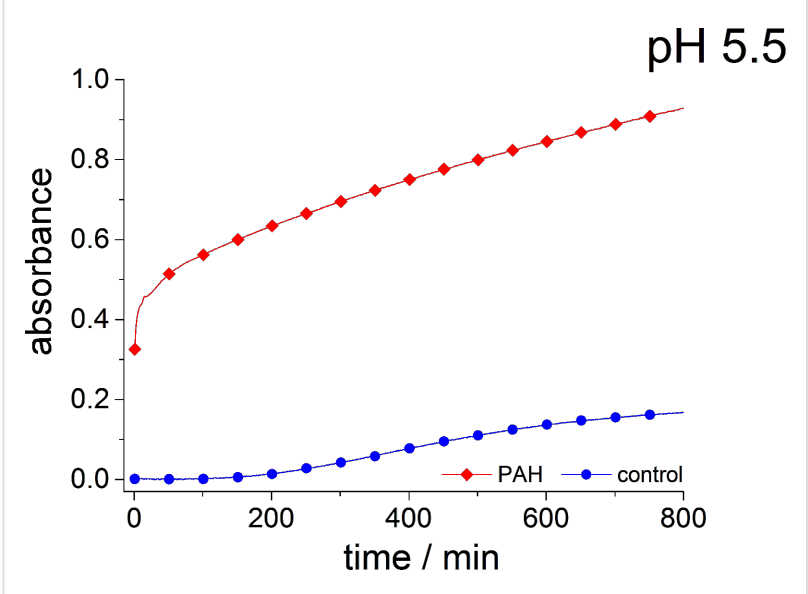

Figure 4: Absorbance of a $90 \mathrm{mM}$ sodium metasilicate solution with $31.25 \mu \mathrm{M}$ PAH and $180 \mathrm{mM}$ hydrogen phosphate (red rhombuses) and of a sodium metasilicate solution $90 \mathrm{mM}$ containing $180 \mathrm{mM}$ hydrogen phosphate (control, blue circles) measured as a function of time up to $800 \mathrm{~min}$.
We have also studied sodium metasilicate solutions containing monomeric allylamine $\left(\mathrm{p} K_{\mathrm{a}} \approx 9.5\right)$ at the same $\mathrm{Si} / \mathrm{N}$ ratio as in the PAH-containing solutions shown in Figure 3 and Figure 4 in order to elucidate possible differences between the polymeric and monomeric compounds. Moreover, monomeric allylamineQ was also used in order to analyse the influence of a quaternary ammonium group with its $\mathrm{pH}$-independent, permanently positive charge surrounded by three hydrophobic methyl groups. The result of the corresponding turbidity measurements at pH 6.8 is shown in Figure 5. First of all, it is evident that the monomeric compounds are much less efficient than the polymer, $\mathrm{PAH}$, in inducing the aggregation process at $\mathrm{pH} 6.8$. This observation agrees with previous studies performed by Behrens et al. [50] on other polyamines. It should be noted that allylamineQ is slightly more efficient than allylamine at $\mathrm{pH} 6.8$ although the charge state of both molecules should be the same (+1 elementary charges).

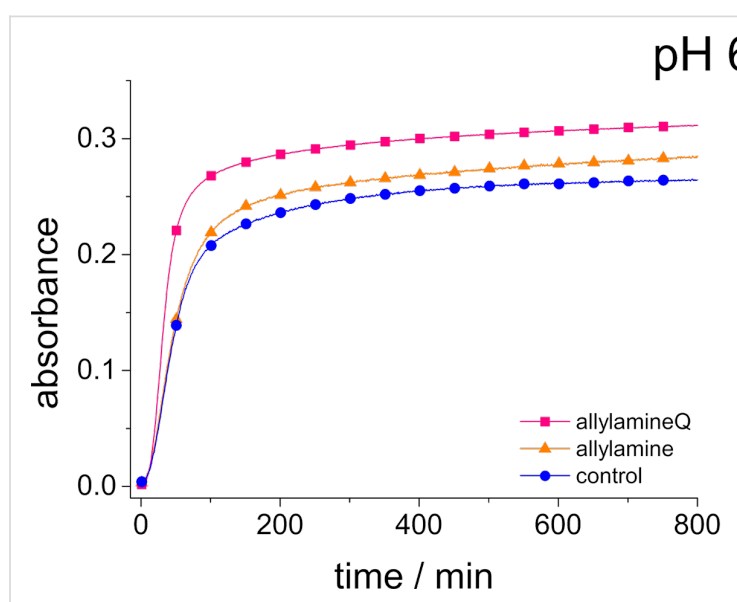

Figure 5: Absorbance of a $90 \mathrm{mM}$ sodium metasilicate solution with $10 \mathrm{mM}$ allylamine (orange triangles), $10 \mathrm{mM}$ allylamineQ (pink squares) and of a sodium metasilicate solution (control, blue circles) measured as a function of time up to 800 minutes.

An explanation for the higher turbidity induced by allylamineQ compared with allylamine could be the influence of hydrophobic interactions induced by the methyl groups. This effect has already been described by Robinson et al. [48] when studying the turbidity of polyamines with different degree of methylation in solution. Interestingly, long-chain polyamines in diatoms are sometimes methylated and lysine residues in silaffins occur as trimethyllysine. It is, therefore, likely that methylation of amine moieties is an important parameter for self-assembly processes. In order to further substantiate this effect, a series of diamines with different degree of methylation was studied, the compounds and their charge state are described in Table 1. The absorbance of sodium metasilicate solutions containing these additives are displayed in Figure 6. The solution containing the compound TMEDA with two methyl groups 
Table 1: Diamines used in the turbidity measurements and their calculated fractions of the charge states at $\mathrm{pH} 7$.

$\mathrm{pH} 7$

EN $\mathrm{H}_{2} \mathrm{~N} \sim \mathrm{NH}_{2}$

MEEN

0.21

fraction of charge states [\%]

$$
\mathrm{H}_{2} \overbrace{50.56}^{\mathrm{NH}_{3}{ }^{+}}
$$

${ }^{+} \mathrm{H}_{3} \mathrm{~N} \sim \mathrm{N}^{\prime}$

69.95

$$
{ }^{+} \mathrm{H}_{3} \mathrm{~N} \overbrace{49.40}^{\mathrm{NH}_{3}{ }^{+}}
$$

${ }^{+} \mathrm{H}_{3} \mathrm{~N} \sim \mathrm{NH}^{+}$

29.84

ENQ

on each of the two nitrogen atoms exhibits by far the largest turbidity. In contrast, the non-methylated compound EN exhibits the lowest absorption, even slightly below the control. The absorbance curves for two partly methylated substances MEEN and ENQ are found in between.

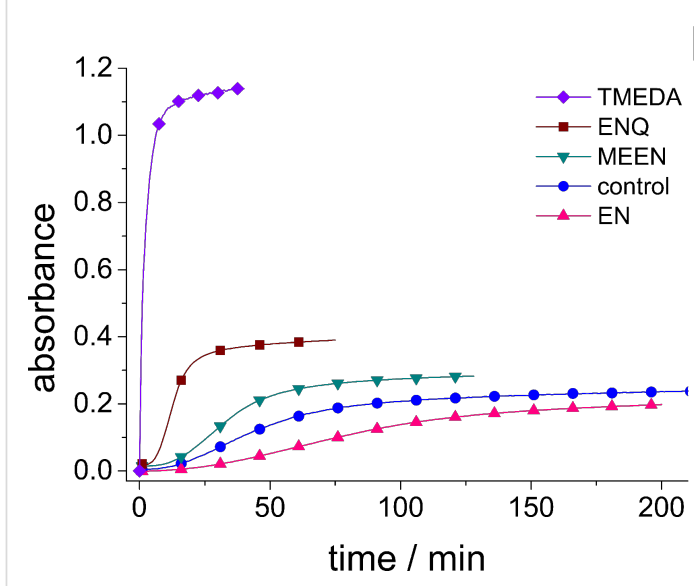

Figure 6: Absorbance of a $90 \mathrm{mM}$ sodium metasilicate solution with $10 \mathrm{mM}$ TMEDA, ENQ, MEEN, and EN (cf. Table 1) and of a pure sodium metasilicate solution (control, blue circles) measured as a function of time up to $800 \mathrm{~min}$.

It can, therefore, be stated that hydrophobic interactions can very strongly influence self-assembly processes taking place in silicic acid solutions. It is interesting to note in this context that Belton et al. [25] observed an increasing third order reaction rate for the monosilicic acid condensation reaction in methylated triamines compared with the non-methylated substance. It is possible, that this enhanced reaction rate is coupled with the enhanced efficiency of the self-assembly processes observed here. For polyallylamine, efficient aggregation under the chosen conditions and at $\mathrm{pH} 5.5$ only occurred in the presence of phosphate (Figure 4). The final question to be answered is therefore related to the influence of phosphate upon the monomercontaining solutions.

Figure 7 shows the absorbance curves for phosphate-containing sodium metasilicate solutions in the presence allylamine and allylamineQ as well as for the pure phosphate-containing

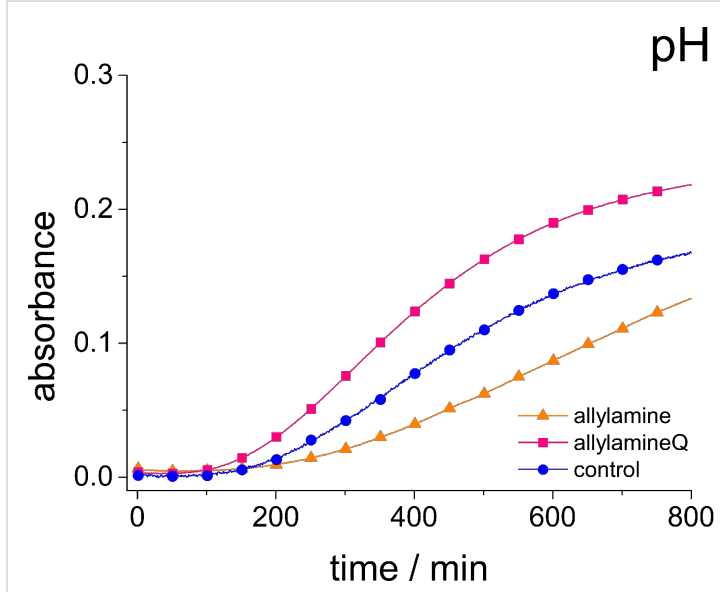

Figure 7: Absorbance of a $90 \mathrm{mM}$ sodium metasilicate solution with $180 \mathrm{mM}$ hydrogen phosphate in the presence of $10 \mathrm{mM}$ allylamine and allylamineQ and of a pure sodium metasilicate solution with $180 \mathrm{mM}$ hydrogen phosphate (control, blue circles) measured as a function of time up to $800 \mathrm{~min}$. 
sodium metasilicate (control). In contrast to the behavior observed for $\mathrm{PAH}$, phosphate does not enhance the aggregate formation in these solutions. The influence of phosphate is even slightly retarding the aggregation. This observation again emphasizes the need to use polymeric additives such as PAH in order to obtain an enhanced aggregation in silicic acid containing solutions.

\section{Conclusion}

The self-assembly processes taking place in sodium metasilicate solutions containing polyamines as well as monomeric amine compounds were studied in the presence and absence of phosphate ions. The present study was especially devoted to the characterization of the initial aggregation steps taking place in such solutions. For this purpose, turbidity measurements were employed as a simple method to detect self-assembly before silica precipitation starts. The following conclusions can be drawn from our studies:

(i) Polyallylamine (PAH) is by far more efficient in inducing self-assembly processes in silicic-acid containing solutions than equivalent amounts of its monomer, allylamine. That means efficient self-assembly necessarily requires the polymeric state of the amine as already pointed out by Behrens et al. [50]. PAH strongly reduces the concentration of soluble silica especially at elevated $\mathrm{pH}$ above 8.5. It is tempting to speculate that $\mathrm{PAH}$ catalyzes the silicic acid polycondensation reaction as suggested by Kröger et al. [1] - in particular at elevated pH. Belton et al. [25] indeed observed an enhanced reaction rate for the silicic acid polycondensation reaction in the presence of different amines at pH 6.8 whereas Behrens et al. [50] did not observe such an effect at $\mathrm{pH} 5.5$. Elucidation of this possible catalytic effect and its dependence on the experimental parameters should be subject of future research.

(ii) Efficient self-assembly takes place in the pure $\mathrm{PAH} /$ silicic acid solution at $\mathrm{pH}$ 6.8. This can be explained by the electrostatic interactions between positively charged polyamines and negatively charged silicic acid oligomers/silica nanoparticles. However, changes of the $\mathrm{pH}$ strongly influence these processes. At $\mathrm{pH} 5.5$, self-assembly in the pure silicic acid/PAH solutions is totally suppressed at the concentrations chosen here. This is explained by the perturbed charge balance caused by the decreasing negative surface charge of the silica nanoparticles at lower $\mathrm{pH}$. However, the introduction of negatively charged phosphate restores the ability of the system to self-assemble. This highlights the necessity of a proper charge balance in the formed aggregates.

(iii) Methylation of the amine groups strongly enhances the tendency for self-assembly in amine-containing silicic acid solu- tions (see also [48]). The enhanced reactivity of methylated polyamines in the silicic acid polycondensation reaction observed by Belton et al. [25] may be related to this fact. That means the degree of methylation provides a further important "tuning" parameter for bioinspired silica synthesis approaches based on the use of LCPAs which should be further exploited in future in vitro studies.

\section{Experimental \\ Reagents and chemicals}

Polyallylamine hydrochloride $\left(\mathrm{PAH} ;\left(\mathrm{C}_{3} \mathrm{H}_{8} \mathrm{ClN}\right)_{n} ; M=\right.$ $15000 \mathrm{~g} / \mathrm{mol}, n \approx 160)$, allylamine $\left(\mathrm{C}_{3} \mathrm{H}_{7} \mathrm{~N} ; M=57.09 \mathrm{~g} / \mathrm{mol}\right)$, ethylenediamine dihydrochloride $\left(\mathrm{EN} ; \mathrm{C}_{2} \mathrm{H}_{8} \mathrm{~N}_{2} \cdot 2 \mathrm{HCl} ; M=\right.$ $133.02 \mathrm{~g} / \mathrm{mol}$ ), $N, N$-dimethylethylenediamine (MEEN; $\left.\mathrm{C}_{4} \mathrm{H}_{12} \mathrm{~N}_{2} ; M=88.15 \mathrm{~g} / \mathrm{mol}\right)$, (2-aminoethyl)trimethylammonium chloride hydrochloride (ENQ; $\mathrm{C}_{5} \mathrm{H}_{15} \mathrm{~N}_{2} \mathrm{Cl} \cdot \mathrm{HCl}$; $M=175.10 \mathrm{~g} / \mathrm{mol}), N, N, N^{\prime}, N^{\prime}$-tetramethylethylenediamine (TMEDA; $\mathrm{C}_{6} \mathrm{H}_{16} \mathrm{~N}_{2} ; M=116.20 \mathrm{~g} / \mathrm{mol}$ ), sodium metasilicate $\left(\mathrm{Na}_{2} \mathrm{SiO}_{3} \cdot 9 \mathrm{H}_{2} \mathrm{O} ; M=284.2 \mathrm{~g} / \mathrm{mol}\right)$, as well as the reagents used for the silicomolybdic acid test (ammonium molybdate $\left(\left(\mathrm{NH}_{4}\right)_{6} \mathrm{Mo}_{7} \mathrm{O}_{24} \cdot 4 \mathrm{H}_{2} \mathrm{O}\right)$, oxalic acid $\left.\left(\mathrm{C}_{2} \mathrm{H}_{2} \mathrm{O}_{4} \cdot 2 \mathrm{H}_{2} \mathrm{O}\right)\right)$ were purchased from Sigma-Aldrich (Germany). The allyltrimethylammonium bromide (allylamineQ; $\mathrm{C}_{6} \mathrm{H}_{14} \mathrm{BrN} ; M=$ $180.09 \mathrm{~g} / \mathrm{mol}$ ) was obtained from ABCR (Germany).

The samples studied in this work were prepared by using purified distilled water (filtersystem: Elga - Purelab Classic, Germany; filter: Gelman Sciences - Supor ${ }^{\circledR} \mathrm{DCF}^{\mathrm{TM}} 0.2 \mu \mathrm{m}$ ). In the following, this deionized water will be called ultrapure water.

\section{Silicomolybdic acid test}

The solutions for the silicomolybdic acid test were prepared and used by following the protocol developed by Spinde et al. [23].

\section{${ }^{29} \mathrm{Si}$ NMR measurements}

To obtain ${ }^{29} \mathrm{Si}$-enriched sodium metasilicate $\left(\mathrm{Na}_{2}{ }^{29} \mathrm{SiO}_{3}\right)$, ${ }^{29} \mathrm{SiO}_{2}$ was melted with sodium carbonate (Fluka), thus forming $\mathrm{Na}_{2}{ }^{29} \mathrm{SiO}_{3}$ in a solid-state reaction.

For liquid-state ${ }^{29} \mathrm{Si}$ NMR measurements, $24.2 \mathrm{mg}$ of $\mathrm{Na}_{2}{ }^{29} \mathrm{SiO}_{3}$ were dissolved in $2 \mathrm{~mL}$ of $\mathrm{D}_{2} \mathrm{O} / \mathrm{H}_{2} \mathrm{O}(1: 1)$ and placed in a container with a Teflon-covered magnetic stirring bar, resulting in a $6030 \mathrm{ppm} \mathrm{SiO}_{2}$ stock solution at $\mathrm{pH} 12$. For the acidic sample, $24.2 \mathrm{mg}$ of $\mathrm{Na}_{2}{ }^{29} \mathrm{SiO}_{3}$ were dissolved in $2 \mathrm{~mL} 0.25 \mathrm{M}$ hydrochloric acid and hydrolyzed for $15 \mathrm{~min}$. Ultrapure water was added to both stock solutions giving a final silicic acid concentration of $4350 \mathrm{ppm}$.

${ }^{29} \mathrm{Si}$ NMR experiments were performed on a Bruker Avance 300 spectrometer operating at a resonance frequency of 
59.63 MHz. For liquid-state ${ }^{29} \mathrm{Si}$ NMR measurements, a commercial $10 \mathrm{~mm} \mathrm{HR}$ probe (56 $6^{\circ}$ flip angle, number of scans $180,60 \mathrm{~s}$ repetition time) was used. Typical $T_{1}$ values for samples in solution were $8-13 \mathrm{~s}$. Waltz $16{ }^{1} \mathrm{H}$ decoupling was applied during signal acquisition. The chemical shift was referenced relative to tetramethylsilane (TMS).

\section{$\mathrm{pH}$ Titration}

The starting solutions were prepared by mixing $2.1 \mathrm{~mL}$ of orthosilicic acid solution $\left(100 \mathrm{mM}, \mathrm{Na}_{2} \mathrm{SiO}_{3}\right)$ with $0.6 \mathrm{~mL}$ of a PAH containing solution ( $2 \mathrm{mM}$ ) or ultrapure water (control). The final ratio of silicon and nitrogen atoms in the polymercontaining sample was $1: 1$ and the starting $\mathrm{pH}$ was 12.7 . The desired $\mathrm{pH}$ values were adjusted by titration with a $2.4 \mathrm{M} \mathrm{HCl}$ stock solution under continuous stirring. The final $\mathrm{SiO}_{2}$ concentration was $70 \mathrm{mM}$. The resulting solution (control) or precipitate $(\mathrm{PAH})$ were transferred into Eppendorf vials and set aside without stirring. The concentration of soluble silicic acid was determined using the well-established silicomolybdic acid test $40 \mathrm{~min}$ after titration.

\section{Turbidity measurements}

To slow down the reaction, the final ratio of silicon and nitrogen atoms in the turbity measurements was changed to 9:1. Turbidity measurements were performed by mixing a silicatecontaining solution A with different amines (solution B).

Preparation of solution A without phosphate: Solution A was prepared by titration of a stock solution of sodium metasilicate (ca. $250 \mathrm{mM}$ ) to $\mathrm{pH} 6.8$ or 5.5 with $2.5 \mathrm{M}$ hydrochloric acid (see final concentrations in Table 2). Finally, the samples were diluted to a Si-concentration of $120 \mathrm{mM}$.

\begin{tabular}{|c|c|c|}
\hline $\begin{array}{l}\text { final concentration (solution A } \\
\text { without phosphate) }\end{array}$ & $\mathrm{pH} 5.5$ & pH 6.8 \\
\hline silica & $120 \mathrm{mM}$ & $120 \mathrm{mM}$ \\
\hline chloride & $220 \mathrm{mM}$ & $180 \mathrm{mM}$ \\
\hline
\end{tabular}

Preparation of solution A with phosphate: Solution A was prepared as described by using $0.5 \mathrm{M}$ phosphoric acid for titration (see final concentration in Table 3). Finally, the samples were diluted to a Si-concentration of $120 \mathrm{mM}$.

Preparation of solution B: The amine-containing solution B was prepared by titration of an amine stock solution (ca. $40 \mathrm{mM}$ or ca. $0.25 \mathrm{mM}$ for PAH) with $2.5 \mathrm{M}$ hydrochloric acid. Afterwards, the solutions were diluted to the final concentrations shown in Table 4.
Table 3: Final concentrations of stock solution A with phosphate.

\begin{tabular}{lll}
$\begin{array}{lll}\text { final concentration (solution A with } \\
\text { phosphate) }\end{array}$ & pH 5.5 & pH 6.8 \\
\hline silica & $120 \mathrm{mM}$ & $120 \mathrm{mM}$ \\
phosphate & $240 \mathrm{mM}$ & $160 \mathrm{mM}$
\end{tabular}

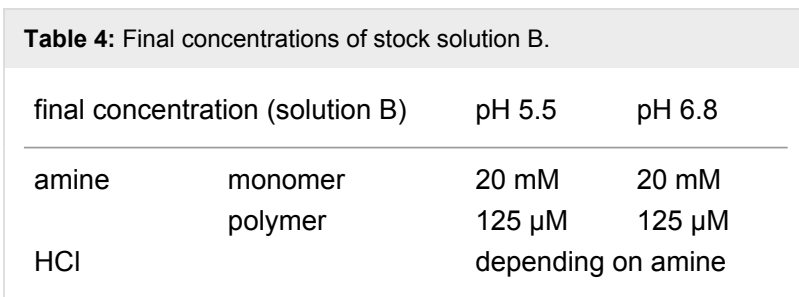

Measurements: All solutions were prepared immediately before use. Both solutions were stored in an ice bath to slow down further reactions. Before starting the measurements, the samples were warmed in a water bath at room temperature for $5 \mathrm{~min}$. Mixing of $1.2 \mathrm{~mL}$ solution A with $0.4 \mathrm{~mL}$ of solution B resulted in the final concentrations displayed in Table 5 and Table 6.

\begin{tabular}{|c|c|c|}
\hline $\begin{array}{l}\text { final concentration (without } \\
\text { phosphate) }\end{array}$ & \multirow{2}{*}{$\begin{array}{l}\mathrm{pH} 5.5 \\
90 \mathrm{mM}\end{array}$} & \multirow{2}{*}{$\begin{array}{c}\mathrm{pH} 6.8 \\
90 \mathrm{mM}\end{array}$} \\
\hline silica & & \\
\hline monomer & $10 \mathrm{mM}$ & $10 \mathrm{mM}$ \\
\hline polymer & $31.25 \mu \mathrm{M}$ & $31.25 \mu \mathrm{M}$ \\
\hline chloride & $165 \mathrm{mM}$ & $135 \mathrm{mM}$ \\
\hline
\end{tabular}

\begin{tabular}{|c|c|c|}
\hline final concentration (with phosphate) & $\mathrm{pH} 5.5$ & $\mathrm{pH} 6.8$ \\
\hline silica & $90 \mathrm{mM}$ & $90 \mathrm{mM}$ \\
\hline monomer & $10 \mathrm{mM}$ & $10 \mathrm{mM}$ \\
\hline polymer & $31.25 \mu \mathrm{M}$ & $31.25 \mu \mathrm{M}$ \\
\hline phosphate & $180 \mathrm{mM}$ & $120 \mathrm{mM}$ \\
\hline
\end{tabular}

An initial absorption spectrum was taken from 400 to $500 \mathrm{~nm}$ on a Varian Cary 50 spectrometer. The solutions were directly mixed in a glass cuvette, shortly shaken and the measurement started immediately. For rapidly reacting solutions (such as with PAH) solution B was given directly into the cuvette, which already contained solution A and was placed in the spectrom- 
eter by moving the pipette from the bottom upwards. The resulting mixture was homogenous and no air bubbles, gradient or sedimentation could be observed. The absorbance was measured as a function of time $\left(t_{\max }=800 \mathrm{~min}\right)$ in continuous mode every minute. Measurements were run overnight. The absorbance at $480 \mathrm{~nm}$ was taken as a measure of turbidity.

\section{Acknowledgements}

Financial support from the Deutsche Forschungsgemeinschaft (grants no. Br 1278/24-1 within the Research Unit FOR 2038 "Nanopatterned Organic Matrices in Biological Silica Mineralization" and Br 1278/ 25-2 within the SPP 1562 "Generation of Multifunctional Inorganic Materials by Molecular Bionics").

\section{References}

1. Kröger, N.; Deutzmann, R.; Bergsdorf, C.; Sumper, M. Proc. Natl. Acad. Sci. U. S. A. 2000, 97, 14133-14138. doi:10.1073/pnas.260496497

2. Sumper, M.; Lorenz, S.; Brunner, E. Angew. Chem., Int. Ed. 2003, 42, 5192-5195. doi:10.1002/anie.200352212

3. Sumper, M.; Brunner, E. Adv. Funct. Mater. 2006, 16, 17-26. doi:10.1002/adfm.200500616

4. Sumper, M.; Brunner, E.; Lehmann, G. FEBS Lett. 2005, 579, 3765-3769. doi:10.1016/j.febslet.2005.06.001

5. Sumper, M.; Lehmann, G. ChemBioChem 2006, 7, 1419-1427. doi:10.1002/cbic.200600184

6. Sumper, M.; Brunner, E. ChemBioChem 2008, 9, 1187-1194. doi:10.1002/cbic.200700764

7. Kröger, N.; Deutzmann, R.; Sumper, M. Science 1999, 286, 1129-1132. doi:10.1126/science.286.5442.1129

8. Kröger, N.; Lorenz, S.; Brunner, E.; Sumper, M. Science 2002, 298, 584-586. doi:10.1126/science.1076221

9. Poulsen, N.; Kröger, N. J. Biol. Chem. 2004, 279, 42993-42999. doi:10.1074/jbc.M407734200

10. Richthammer, P.; Börmel, M.; Brunner, E.; van Pée, K.-H. ChemBioChem 2011, 12, 1362-1366. doi:10.1002/cbic.201000775

11. Matsunaga, S.; Sakai, R.; Jimbo, M.; Kamiya, H. ChemBioChem 2007, 8, 1729-1735. doi:10.1002/cbic.200700305

12. Gröger, C.; Lutz, K.; Brunner, E. Cell Biochem. Biophys. 2008, 50, 23-39. doi:10.1007/s12013-007-9003-2

13. Zhang, B.-R.; Chen, Y.-N.; Li, F.-T. Colloids Surf., A 2011, 385, 11-19. doi:10.1016/j.colsurfa.2011.03.062

14. Demadis, K. D.; Neofotistou, E. Chem. Mater. 2007, 19, 581-587. doi:10.1021/cm062370d

15. Mizutani, T.; Nagase, H.; Fujiwara, N.; Ogoshi, H. Bull. Chem. Soc. Jpn. 1998, 71, 2017-2022. doi:10.1246/bcsj.71.2017

16. Brunner, E.; Lutz, K.; Sumper, M. Phys. Chem. Chem. Phys. 2004, 6, 854-857. doi:10.1039/b313261g

17. Lutz, K.; Gröger, C.; Sumper, M.; Brunner, E. Phys. Chem. Chem. Phys. 2005, 7, 2812-2815. doi:10.1039/b505945c

18. Sumper, M. Angew. Chem., Int. Ed. 2004, 43, 2251-2254. doi:10.1002/anie.200453804

19. Annenkov, V. V.; Danilovtseva, E. N.; Likhoshway, Y. V.; Patwardhan, S. V.; Perry, C. C. J. Mater. Chem. 2008, 18, 553-559. doi:10.1039/b716367n

20. Coradin, T.; Lopez, P. J. ChemBioChem 2003, 4, 251-259. doi:10.1002/cbic. 200390044
21. Annenkov, V. V.; Danilovtseva, E. N.; Pal'shin, V. A.; Aseyev, V. O.; Petrov, A. K.; Kozlov, A. S.; Patwardhan, S. V.; Perry, C. C. Biomacromolecules 2011, 12, 1772-1780. doi:10.1021/bm2001457

22. Danilovtseva, E. N.; Pal'shin, V. A.; Likhoshway, Y. V.; Annenkov, V. V. Adv. Sci. Lett. 2011, 4, 616-621. doi:10.1166/asl.2011.1262

23. Spinde, K.; Pachis, K.; Antonakaki, I.; Paasch, S.; Brunner, E.; Demadis, K. D. Chem. Mater. 2011, 23, 4676-4687. doi:10.1021/cm201988g

24. Preari, M.; Spinde, K.; Lazic, J.; Brunner, E.; Demadis, K. D. J. Am. Chem. Soc. 2014, 136, 4236-4244. doi:10.1021/ja411822s

25. Belton, D. J.; Patwardhan, S. V.; Annenkov, V. V.; Danilovtseva, E. N.; Perry, C. C. Proc. Natl. Acad. Sci. U. S. A. 2008, 105, 5963-5968. doi:10.1073/pnas.0710809105

26. Bernecker, A.; Wieneke, R.; Riedel, R.; Seibt, M.; Geyer, A.; Steinem, C. J. Am. Chem. Soc. 2010, 132, 1023-1031. doi:10.1021/ja9061163

27. Wieneke, R.; Bernecker, A.; Riedel, R.; Sumper, M.; Steinem, C.; Geyer, A. Org. Biomol. Chem. 2011, 9, 5482-5486. doi:10.1039/c1ob05406f

28. Patwardhan, S. V.; Clarson, S. J. Silicon Chem. 2002, 1, 207-214. doi:10.1023/A:1021243810915

29. Patwardhan, S. V.; Mukherjee, N.; Clarson, S. J. Silicon Chem. 2002, 1, 47-54. doi:10.1023/A:1016026927401

30. Menzel, H.; Horstmann, S.; Behrens, P.; Bärnreuther, P.; Krueger, I.; Jahns, M. Chem. Commun. 2003, 2994-2995. doi:10.1039/b310201g

31. Iler, R. K. The chemistry of silica : solubility, polymerization, colloid and surface properties, and biochemistry; Wiley: New York, 1979; p 866.

32. Bäuerlein, E.; Behrens, P.; Epple, M. Handbook of Biomineralization; Wiley-VCH: Weinheim, 2007; Vol. 1-3, pp $1269 \mathrm{ff}$. doi:10.1002/9783527619443

33. Mullin, J. B.; Riley, J. P. Anal. Chim. Acta 1955, 12, 162-176. doi:10.1016/S0003-2670(00)87825-3

34. Coradin, T.; Eglin, D.; Livage, J. Spectroscopy 2004, 18, 567-576. doi:10.1155/2004/356207

35. Chisholm, S. W.; Azam, F.; Eppley, R. W. Limnol. Oceanogr. 1978, 23, 518-529. doi:10.4319/lo.1978.23.3.0518

36. Kinrade, S. D.; Hamilton, R. J.; Schach, A. S.; Knight, C. T. G. J. Chem. Soc., Dalton Trans. 2001, 961-963. doi:10.1039/b010111g 37. Amjad, Z.; Zuhl, B. Mater. Perform. 2009, 48, 48-52.

38. Ketsetzi, A.; Stathoulopoulou, A.; Demadis, K. D. Desalination 2008, 223, 487-493. doi:10.1016/j.desal.2007.01.230

39. Vrieling, E. G.; Beelen, T. P. M.; van Santen, R. A.; Gieskes, W. W. C. Prog. Ind. Microbiol. 1999, 35, 39-51. doi:10.1016/S0079-6352(99)80096-4

40. Vrieling, E. G.; Beelen, T. P. M.; van Santen, R. A.; Gieskes, W. W. C. Angew. Chem., Int. Ed. 2002, 41, 1543-1546. doi:10.1002/1521-3773(20020503)41:9<1543::AID-ANIE1543>3.0.CO; 2-B

41. Hazelaar, S.; Van Der Strate, H. J.; Gieskes, W. W. C.; Vrieling, E. G. J. Phycol. 2005, 41, 354-358. doi:10.1111/j.1529-8817.2005.04131.x

42. Gordon, R.; Drum, R. W. In The Chemical Basis of Diatom Morphogenesis; Jeon, K. W.; Jarvik, J., Eds.; International Review of Cytology, Vol. 150; Academic Press, 1994; pp 243-372.

43. Nagy, J. B.; Engelhardt, G.; Michel, D. Adv. Colloid Interface Sci. 1985, 23, 67-128. doi:10.1016/0001-8686(85)80017-8

44. Kobayashi, S.; Tokunoh, M.; Saegusa, T.; Mashio, F. Macromolecules 1985, 18, 2357-2361. doi:10.1021/ma00154a004

45. Rao, G. V. R.; Konishi, T.; Ise, N. Macromolecules 1999, 32 , 7582-7586. doi:10.1021/ma990851v 
46. Ong, S.; Zhao, X.; Eisenthal, K. B. Chem. Phys. Lett. 1992, 191, 327-335. doi:10.1016/0009-2614(92)85309-X

47. Leung, K.; Nielsen, I. M. B.; Criscenti, L. J. J. Am. Chem. Soc. 2009, 131, 18358-18365. doi:10.1021/ja906190t

48. Robinson, D. B.; Rognlien, J. L.; Bauer, C. A.; Simmons, B. A. J. Mater. Chem. 2007, 17, 2113-2119. doi:10.1039/b700514h

49. Trompette, J. L.; Meireles, M. J. Colloid Interface Sci. 2003, 263, 522-527. doi:10.1016/S0021-9797(03)00397-7

50. Behrens, P.; Jahns, M.; Menzel, H. The Polyamine Silica System: A Biomimetic Model for the Biomineralization of Silica. In Handbook of Biomineralization; Bäuerlein, E.; Behrens, P., Eds.; Wiley-VCH Verlag GmbH, 2007; pp 2-18. doi:10.1002/9783527619443.ch25

\section{License and Terms}

This is an Open Access article under the terms of the Creative Commons Attribution License

(http://creativecommons.org/licenses/by/2.0), which permits unrestricted use, distribution, and reproduction in any medium, provided the original work is properly cited.

The license is subject to the Beilstein Journal of

Nanotechnology terms and conditions:

(http://www.beilstein-journals.org/bjnano)

The definitive version of this article is the electronic one which can be found at: doi:10.3762/bjnano.5.211 